\title{
Reactive Hot Pressing of Titanium Nitride-Titanium Diboride Composites at Moderate Pressures and Temperatures
}

\author{
Lingappa Rangaraj and Canchi Divakar \\ High Pressure Laboratory, Materials Science Division, National Aerospace Laboratories, Bangalore 560017, India
}

Vikram Jayaram*

Department of Metallurgy, Indian Institute of Science, Bangalore 560012, India

\begin{abstract}
Dense composites in the Ti-B-N system have been produced by reactive hot pressing of titanium and $B N$ powders. The effect of the addition of a small amount of nickel (1-3 wt \%) on the reaction kinetics and densification of $\mathrm{TiN}_{-} \mathrm{TiB}_{2}(40 \mathrm{vol} \%)$ composite has been studied. Composites of $\sim 99 \%$ of theoretical density have been produced at $1600^{\circ} \mathrm{C}$ under $40 \mathrm{MPa}$ for $30 \mathrm{~min}$ with $1 \%$ nickel. The hardness and fracture toughness of these composites are $24.5 \pm 0.97 \mathrm{GPa}$ and $6.53 \pm 0.27$ $\mathrm{MPa} \cdot \mathrm{m}^{1 / 2}$, respectively. The microstructural studies on samples produced at lower temperatures indicate the formation of a transient liquid phase, which enhances the kinetics of the reaction and densification of the composite.
\end{abstract}

\section{Introduction}

$\mathbf{R}$ EFRACTORY transition-metal borides, carbides, and nitrides are candidates for applications that require hardness and wear resistance, especially at elevated temperatures. One of the attractive systems, by virtue of the stability and hardness of the constituents, is the $\mathrm{TiN}-\mathrm{TiB}_{2}$ system, which is the focus of the present work. Titanium-based ceramics (borides, carbides, and nitrides) are an outstanding group of refractory materials with high hardness, elastic modulus, and abrasion resistance, good hightemperature strength, and moderate high-temperature oxidation resistance. Titanium-based ceramics possess good electrical and thermal conductivity compared with those of alloyed metals; thus, they can be electrical discharge machined. Because the melting temperatures of $\mathrm{TiN}$ and $\mathrm{TiB}_{2}$ are extremely high, pressureless sintering of these materials, in monolithic and composite form, requires high temperatures. High-temperature sintering studies that have yielded moderate to high relative densities include those of Shobu and Watanabe ${ }^{1}$ on $\operatorname{Ti}\left(\mathrm{C}_{0.5} \mathrm{~N}_{0.5}\right)-30 \% \mathrm{TiB}_{2}, \operatorname{Ti}\left(\mathrm{C}_{0.5} \mathrm{~N}_{0.5}\right)-$ $60 \% \mathrm{TiB}$, and $\mathrm{TiN}-30 \% \mathrm{TiB}_{2}$ composites at $1900^{\circ} \mathrm{C}$, Watanabe et al. ${ }^{4}$ on $\mathrm{Ti}(\mathrm{CN})-30 \% \mathrm{TiB}_{2}$ at $1700^{\circ}-2000^{\circ} \mathrm{C}$, Shobu et al. ${ }^{3}$ on hot pressing of TiN- $(20 \%-80 \%) \mathrm{TiB}_{2}$ at $1800^{\circ}-1850^{\circ} \mathrm{C}$, and Graziani et al. $^{4}$ on hot pressing and sintering of TiN-20\% $\mathrm{TiB}_{2}$ with $1-1.5$ wt $\%$ nickel at $1700^{\circ}-2150^{\circ} \mathrm{C}$.

To circumvent the high sintering temperatures needed, reactive processing methods have been evolved to enable the achievement of high density at reasonable temperatures. Zhang and co-workers ${ }^{5,6}$ studied the reactive hot pressing (RHP) of $\mathrm{TiH}_{2}+\mathrm{BN}+\mathrm{B}_{4} \mathrm{C}$ (with $2 \mathrm{wt} \%$ nickel as an additive) at $1850^{\circ} \mathrm{C}$ and $25 \mathrm{MPa}$ to yield $\mathrm{TiB}_{2}$ and $\mathrm{Ti}\left(\mathrm{C}_{\mathrm{O}_{5}} \mathrm{~N}_{0}\right)$ and that of $\mathrm{TiH}_{3}+\mathrm{BN}$ with 0-5 wt $\%$ nickel

Z. A. Munir-contributing editor

Manuscript No. 10381. Received July 11, 2003; approved April 28, 2004.

Based in part on the dissertation submitted by L. Rangaraj for the degree M.Sc. in Engineering, Indian Institute of Science, Bangalore, India, 2003.

*Member, American Ceramic Society. as an additive. In the latter case, the reaction kinetics showed the formation of $\mathrm{TiN}$ at $1000^{\circ} \mathrm{C}, \mathrm{TiB}_{2}$ at $1200^{\circ} \mathrm{C}$, and the reaction completing at $1600^{\circ} \mathrm{Cto}$ yield a stoichiometricmixture of TiN and $\mathrm{TiB}_{2}$. The composites hot-pressed at $1850^{\circ} \mathrm{C}$ under $30 \mathrm{MPa}$ for 30 min without nickel showed $98 \%$ relative density (RD), whereas the addition of $1 \mathrm{wt} \%$ nickel increased the RD to $99.9 \%$ and further addition of nickel (2 wt \%) appeared to decrease the RD to $99.2 \%$, Tomoshige et al. ${ }^{7}$ produced $\mathrm{TiB}_{2}-\mathrm{TiN}(10-60 \mathrm{~mol} \% \mathrm{TiN}) \mathrm{com}-$ posites by combustion synthesis using titanium, boron, and BN powders. Lee et al. ${ }^{8}$ used field activation to produce nanocrystalline $\mathrm{TiB}_{2}-\mathrm{TiN}$ composite starting with titanium, boron, and $\mathrm{BN}$ powders followed by densification up to 9()$\%-97 \% \mathrm{RD}$.

The reactive hot pressing of titanium and $\mathrm{BN}$ mixtures with substantial nickel additions has been studied by several processes, including thermal explosion and high-pressure consolidation. ${ }^{9-11}$ The 3Ti-2BN blends with the stoichiometric ratio for full conversion to $\mathrm{TiN}$ and $\mathrm{TiB}_{2}$, treated at $110\left(0^{\circ} \mathrm{C}\right.$, showed incomplete reaction, and compositions with nickel addition showed very fine microstructures of $\mathrm{TiN}$ and $\mathrm{TiB}_{2}$, with substantial amounts of nickel and $\mathrm{Ni}_{3} \mathrm{Ti}$. The significant densification of such a stoichiometric blend with large amounts of nickel at $1200^{\circ} \mathrm{C}$ for $20 \mathrm{~h}$ resulted in full conversion of reactants to products with final $\mathrm{RD}$ of $\sim 92 \%$, but with substantially decreased hardness, compared with the metal-free composite, because of the large amount of retained nickel. High RD values $(99 \%)$ were obtained when pressureassisted thermal explosion at 10()()$^{\circ}-110()^{\circ} \mathrm{C}$ was used. The morphology of the phases showed that TiN was most probably formed by interfacial reaction between $\mathrm{BN}$ and liquid $\mathrm{Ti}$, $\mathrm{Ni}$, whereas $\mathrm{TiB}$, was formed by a dissolution and reprecipitation mechanism.

Our point of departure is to aldiress the relative luck of attention paid to the conditions under which a predominantly ceramic composition can be produced by simple hot pressing, i.e., in the absence of explosions and high pressisure, and also with the least addition of nickel, which otherwise is deleterious to the hardness of the composite. In the presence of nickel, transicnt liquid phases can persist below the melting point of nickel because of the presence of deep eutectics in the $\mathrm{Ni}^{\prime} \mathrm{I}^{*} \mathrm{i}$ system. Such a liquid is undoubtedly the cause of rapid densification and reaction when large amounts $(25-30 w t \%)$ of nickel $u^{\prime} \mathrm{c}$ added. However, the situation can be markedly different when this amount is decreased to $\sim 1 \%$. The present investigation accordingly has been undertaken to establish the conditions for reaction kinetics and mechar nisms of densification in stoichiometric mixtures of titanium and $\mathrm{BN}$.

\section{Lxperimental Procedures}

The TiN-TiB, composite was produced by the reactive hor pressing of titanium and $\mathrm{BN}$ powders using the reaction

$3 \mathrm{Ti}+2 \mathrm{BN} \rightarrow 2 \mathrm{TiN}+\mathrm{TiB}_{2}$ 


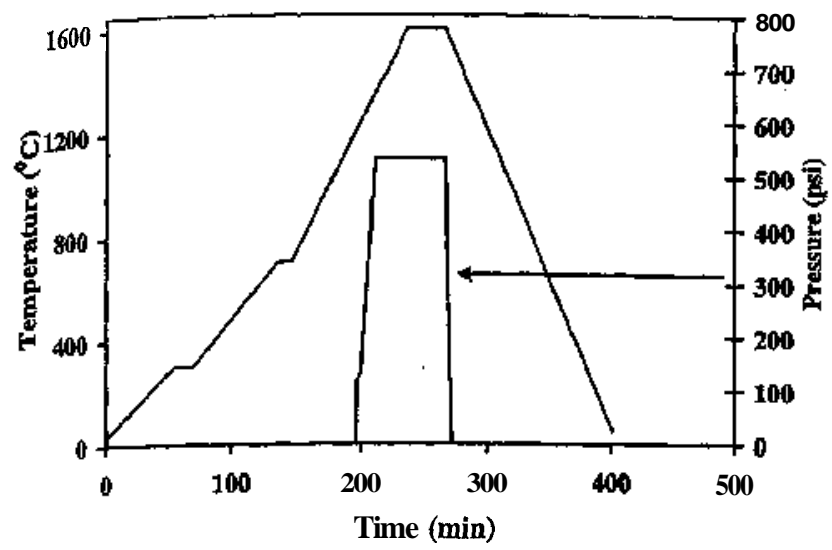

Fig. 1. Typical temperature-time-pressure cycle used to prepare composite at $40 \mathrm{MPa}$ and $1600^{\circ} \mathrm{C}$ for $30 \mathrm{~min}$. Oil pressure in the ram is shown. Load application was initiated at $1200^{\circ} \mathrm{C}$ and final pressure reached in 15 min.

\section{(1) Materials and Process}

The raw materials used were titanium powder $\sim 99.5 \%$ pure and particle size $\sim 10-15 \mu \mathrm{m}$ (SPMS Powder Metal, France), BN powder $\sim 99.5 \%$ pure and particle size $\sim 5 \mu \mathrm{m}$ (Alpha Chemicals, India), and nickel powder $-99.5 \%$ pure and particle size $\sim 4 \mu \mathrm{m}$ (INCO, London, U.K.). The required amounts of titanium and BN powders (74.32 and $25.68 \mathrm{wt} \%)$ were mixed in a centrifugal ball mill (Model Pulverisette 6, Fritsch, Oberstein, Germany) for $24 \mathrm{~h}$ in hexane medium. The mixing was conducted at a ball:powder ratio of 10:1. The powder mixtures were dried at $-100^{\circ} \mathrm{C}$ for $\sim 5$ h. Powder mixtures with various amounts of nickel also were prepared. The dried powder mixtures were hot-pressed in a high-density graphite die (internal diameter $25-30 \mathrm{~mm}$ and height $70 \mathrm{~mm}$ ). To avoid direct contact between the powder and the die/punch assembly, flexible graphite sheet $(0.2 \mathrm{~mm}$ thick $)$ was used. The RHP experiments were conducted in a vacuum hot press (Materials Research Furnaces, Suncook, NH).

A typical reactive hot-pressing experiment involved the following steps. After the furnace was evacuated to $5 \times 10^{-5}$ torr $(6.5$ $\mathrm{mPa}$ ), the samples were heated to $300^{\circ} \mathrm{C}$ at $5^{\circ} \mathrm{C} / \mathrm{min}$, held for 30 min to remove gases present on the surface of the particles, and heated to $700^{\circ} \mathrm{C}$ at $6^{\circ} \mathrm{C} / \mathrm{min}$ and held for $10 \mathrm{~min}$. The samples were finally heated to the required temperature at $10^{\circ} \mathrm{C} / \mathrm{min}$ and held for various times (1-30 min). The pressure of $40 \mathrm{MPa}$ was usually applied within 15 min before reaching the final temperature, held for the required time, and released after 5 min during the cooling cycle. Oil pressure of 532-745 lb/in. ${ }^{2}$ (3.67-5.14 MPa) was generated to apply $40 \mathrm{MPa}$ pressure on the sample. The assembly was cooled at $10^{\circ} \mathrm{C} / \mathrm{min}$. Typical time-temperature and timepressure cycles are shown in Fig. 1.

Most of the experiments were conducted in the temperature range $1400^{\circ}-1850^{\circ} \mathrm{C}$ for $30 \mathrm{~min}$ with and without nickel addition. The application of pressure was started at $1200^{\circ} \mathrm{C}$ and required pressure $(40 \mathrm{MPa})$ reached in $15 \mathrm{~min}$. The effect of an early application of pressure and nickel addition on the reaction kinetics and densification in the RHP experiments was studied in the temperature range $1100^{\circ}-1475^{\circ} \mathrm{C}$ for $1-30 \mathrm{~min}$. In these latter experiments, the application of pressure was started at $950^{\circ} \mathrm{C}$ and required pressure $(40 \mathrm{MPa})$ reached in $15 \mathrm{~min}$.

\section{(2) Characterization}

The top and bottom surfaces of reactive hot-pressed composites were ground and polished using $\mathrm{SiC}$ abrasive paper and diamond paste down to $1 \mu \mathrm{m}$, followed by ultrasonic cleaning with alcohol. X-ray diffraction (XRD) patterns were recorded (Philips, Eindhoven, The Netherlands), using $\mathrm{CuK} \alpha$ radiation with a graphite monochromator in the diffracted beam and a reflection geometry to identity phases present and determine the lattice parameter of TiN in the composite. Density and porosity measurements were conducted using the Archimedes method after boiling the samples in water for $1 \mathrm{~h}$ and cooling to room temperature. Vickers hardness measurements (Model HSV-20, Shimadzu Co., Kyoto, Japan)

Table I. Properties of Composites Produced without and with Nickel Addition ${ }^{\dagger}$

\begin{tabular}{|c|c|c|c|c|c|}
\hline $\begin{array}{l}\text { Sample } \\
\text { No. }\end{array}$ & $\begin{array}{l}\text { Experimental conditions } \\
\text { (MPa/ } /{ }^{\circ} \mathrm{C} / \text { min) } \\
\text { (with Ni addition) }\end{array}$ & $\begin{array}{c}\text { Density }\left(\mathrm{g} / \mathrm{cm}^{3}\right) \\
(\% \mathrm{RD})\end{array}$ & Porosity (\%) & Hardness (GPa) & $\begin{array}{l}\text { Fracture toughness } \\
\left(\mathrm{MPa}^{2} \mathrm{~m}^{7 / 2}\right)\end{array}$ \\
\hline 1 & $40 / 1400 / 30$ & $\begin{array}{c}3.9711 \pm 0.0016 \\
(78.5)\end{array}$ & 9.14 & & \\
\hline 2 & $40 / 1600 / 30$ & $\begin{array}{c}4.4975 \pm 0.0025 \\
(88.8)\end{array}$ & 2.08 & $16.8 \pm 2.33$ & \\
\hline 3 & $40 / 1750 / 30$ & $\begin{array}{c}4.9420 \pm 0.0008 \\
(97.6)\end{array}$ & 0.6 & $24.0 \pm 0.9$ & $5.68 \pm 0.28$ \\
\hline 4 & $40 / 1850 / 30$ & $\begin{array}{c}4.9718 \pm 0.0006 \\
(98.2)\end{array}$ & 0.1 & $24.5 \pm 0.72$ & $6.03 \pm 0.4$ \\
\hline 5 & $\begin{array}{c}40 / 1400 / 1 \\
(1 \%)\end{array}$ & $\begin{array}{c}4.7151 \pm 0.0105 \\
(92.73)\end{array}$ & 0.75 & $17.2 \pm 1.76$ & \\
\hline 6 & $\begin{array}{c}40 / 1400 / 30 \\
(1 \%)\end{array}$ & $\begin{array}{c}4.9322 \pm 0.0056 \\
(97)\end{array}$ & 0.09 & $21.34 \pm 1.6$ & \\
\hline 7 & $\begin{array}{c}40 / 1550 / 1 \\
(1 \%)\end{array}$ & $\begin{array}{c}4.8559 \pm 0.0036 \\
(95.5)\end{array}$ & 0.77 & $19.6 \pm 0.87$ & $6.76 \pm 0.18$ \\
\hline 8 & $\begin{array}{c}40 / 1600 / 1 \\
(1 \%)\end{array}$ & $\begin{array}{c}4.9169 \pm 0.0053 \\
(96.7)\end{array}$ & 0.33 & $22.4 \pm 0.77$ & $5.35 \pm 0.52$ \\
\hline 9 & $\begin{array}{c}40 / 1600 / 15 \\
(1 \%)\end{array}$ & $\begin{array}{c}5.0085 \pm 0.0043 \\
(98.5)\end{array}$ & & $23.4 \pm 0.46$ & $5.89 \pm 0.52$ \\
\hline 10 & $\begin{array}{l}40 / 1600 / 30 \\
(1 \%)\end{array}$ & $\begin{array}{c}5.0593 \pm 0.0029 \\
(99.5)\end{array}$ & & $24.6 \pm 0.97$ & $6.53 \pm 0.27$ \\
\hline 11 & $\begin{array}{c}40 / 1750 / 30 \\
(1 \%)\end{array}$ & $\begin{array}{c}4.9627 \pm 0.0026 \\
(97.6)\end{array}$ & & & \\
\hline 12 & $\begin{array}{c}40 / 1400 / 1 \\
(3 \%)\end{array}$ & $\begin{array}{c}4.9446 \pm 0.0049 \\
(96.4)\end{array}$ & 0.565 & $16.9 \pm 1.32$ & \\
\hline 13 & $\begin{array}{c}40 / 1400 / 30 \\
(3 \%)\end{array}$ & $\begin{array}{c}4.9754 \pm 0.0014 \\
\quad(97)\end{array}$ & 0.34 & $19.9 \pm 0.93$ & \\
\hline 14 & $\begin{array}{c}40 / 1600 / 30 \\
(3 \%)\end{array}$ & $\begin{array}{c}5.0266 \pm 0.0014 \\
(98)\end{array}$ & & $22.7 \pm 1.25$ & $6.39 \pm 0.15$ \\
\hline
\end{tabular}


were performed on a tester at a test load of $500 \mathrm{~g}(4.9 \mathrm{~N})$ and a holding period of $15 \mathrm{~s}$. An average of 10-15 readings was taken for each reported value. The indentation fracture toughness was determined by measuring the radial crack lengths on samples at a test load of 10-20 kgs (98-196 N). The equation derived by Niihara $e t$ al. ${ }^{12}$ was used to calculate the fracture toughness $\left(K_{\mathrm{I} C}\right)$ of the composite. Microstructural observations of polished surfaces were made using optical microscopy and scanning electron microscopy (SEM; Model 440i, LEO Electron Microscopy, Fort Cambridge, U.K.) with energy-dispersive X-ray analysis (EDAX).

\section{Results}

Initially, the results on the composites produced with and without nickel addition in the temperature range $1400^{\circ}-1850^{\circ} \mathrm{C}$ for 1-30 $\mathrm{min}$ are presented. The role of nickel addition and effect of pressure application at lower temperature in the temperature range $1100^{\circ}-1475^{\circ} \mathrm{C}$ for $1 \mathrm{~min}$ are described later. The experimental conditions and properties of the composites are presented in Table I.

\section{(1) High-Temperature Densification $\left(1400^{\circ}-1850^{\circ} \mathrm{C}\right)$}

The XRD patterns of the pressed surface of the composites without nickel addition produced at $40 \mathrm{MPa}$ and $1400^{\circ}-1850^{\circ} \mathrm{C}$ for $30 \mathrm{~min}$ are shown in Fig. 2. At $1400^{\circ} \mathrm{C}$, the strong peaks of TiN and $\mathrm{TiB}_{2}$ with a weak signal of the $\mathrm{BN} 100 \%$ peak are evident. However, the $\mathrm{BN}$ peak does not appear on the surface parallel to the loading direction. The appearance of $\mathrm{BN}$ at the surface of the pellet may be due to the loss of some titanium in reaction with the graphite die. Density of the composite produced at $1400^{\circ} \mathrm{C}$ is only $78.5 \% \mathrm{RD}$. At $\sim 1600^{\circ} \mathrm{C}$, the reaction is completed and the density is $89 \% \mathrm{RD}$. The samples show an improvement of density as the temperature increases: $78.5 \%$ at $1400^{\circ} \mathrm{C}$ to $98.2 \%$ at $1850^{\circ} \mathrm{C}$ (Table I).

The addition of $1 \%$ nickel helps in the improvement of density to $97 \%\left(1400^{\circ} \mathrm{C}\right.$ for $\left.30 \mathrm{~min}\right)$ and $99.5 \%\left(1600^{\circ} \mathrm{C}\right.$ for $\left.30 \mathrm{~min}\right)$. The density-temperature plots of the composites produced with $1 \%$ nickel and without nickel for $30 \mathrm{~min}$ are shown in Fig. 3. The density of the composite with $1 \%$ nickel produced at $1600^{\circ} \mathrm{C}$ shows the increase in density from $\sim 96.5$ to $>99.5 \%$ as the time increases from 1 to $30 \mathrm{~min}$. At $1400^{\circ} \mathrm{C}$, the corresponding increase in density is from $93 \%$ ( $1 \mathrm{~min}$ ) to $97 \%$ (30 $\mathrm{min})$.

The variation of density as a function of nickel content of the composite produced at $1400^{\circ}$ and $1600^{\circ} \mathrm{C}$ under $40 \mathrm{MPa}$ for 30 min is shown in Fig. 4. At $1400^{\circ} \mathrm{C}$, the density increases from $78.5 \%$ to $97 \%$ with $1 \%$ nickel addition and does not improve with further addition of nickel $(3 \%)$. At $1600^{\circ} \mathrm{C}$, the density increases

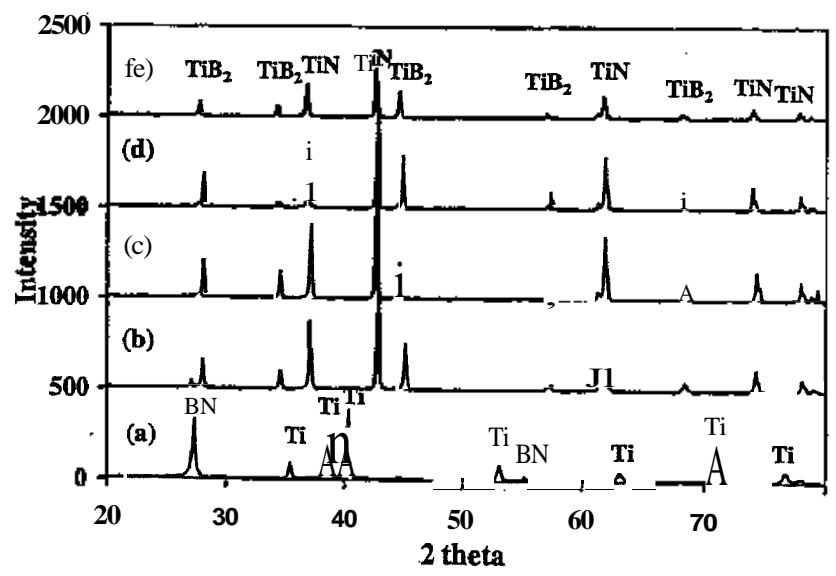

Fig. 2. XRD patterns of (a) powder mixture and the composite produced at $40 \mathrm{MPa}$ for $30 \mathrm{~min}$ at (b) $1400^{\circ}$, (c) $1600^{\circ}$, (d) $1750^{\circ}$, and (e) $1850^{\circ} \mathrm{C}$ Reaction is completed at $-1400^{\circ} \mathrm{C}$ and the only identified phases are TiN and $\mathrm{TiB}_{2}$.

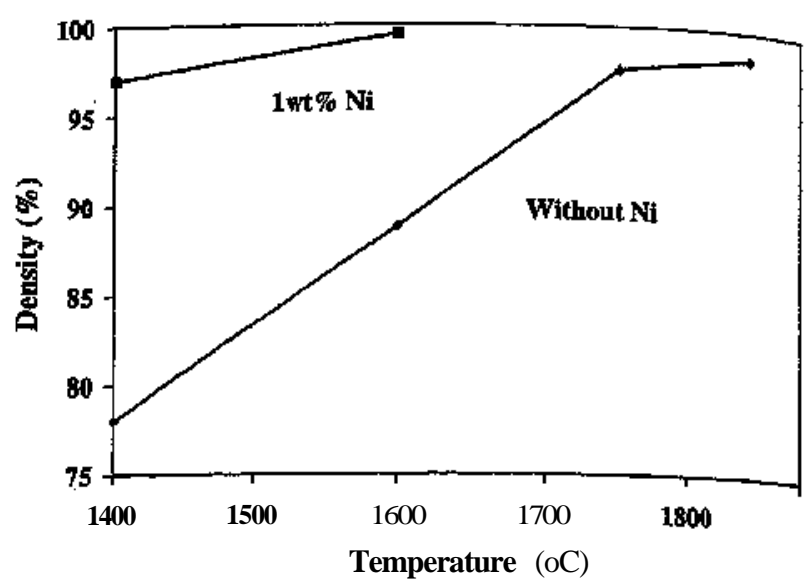

Fig. 3. Density versus temperature plot of the composite produced at 40 $\mathrm{MPa}$ for $30 \mathrm{~min}$ without and with $1 \%$ nickel addition. Improvement of density with nickel addition is evident.

from $89 \%$ to $99.5 \%$ with $1 \%$ nickel, and further increase in nickel (3\%) content decreases the density to $98 \%$. The major role of nickel lies in its ability to complete densification by $1600^{\circ} \mathrm{Cand}$ its impact at higher temperatures is marginal. Experiments conducted at $1400^{\circ} \mathrm{C}$, which is lower than the melting point of nicket, demonstrate the dramatic role of nickel in enhancing densification, The addition of nickel in quantities as small as $1 \%$ enables near-theoretical densities $(99.5 \%)$ to be reached at temperatures as low as $1600^{\circ} \mathrm{C}$. Such a material possesses a hardness as high as $24.5 \mathrm{GPa}$, which is comparable with the hardness achieved without nickel in samples of similar RD that are produced at $1750^{\circ}-$ $1850^{\circ} \mathrm{C}$ (Table I). Typical optical micrographs of the composites produced without and with nickel at $1400^{\circ} \mathrm{C}$ for $30 \mathrm{~min}$ are shown in Fig. 5. The addition of nickel shows substantial decrease in porosity. Typical SEM micrographs of the composites with $1 \%$ and $3 \%$ nickel produced at $1600^{\circ} \mathrm{C}$ for $30 \mathrm{~min}$ are shown in Fig. 6 . Residual nickel is shown as bright particles that are located at interphase boundaries.

TiN can form over a wide range of nonstoichiometric compositions with various N:Ti ratios. ${ }^{13}$ The lattice parameter of TiN in composites without and with nickel addition is 4.2419-4.2439 A and 4.24394.2441 A, respectively, which is very close to the theoretical value 4.24193 A (Powder Diffraction File (PDF) No. 38-1420, International Centre for Diffraction Data, Newtown Square, PA). The lattice plane spacings are close to the values for monoliths of TiN and TiB, (PDF No. 35-0741) and are in agreement with those obtained by combustion synthesis. ${ }^{7}$ These results indicate that stoichiometric TiN is produced in the composite (in solid-state reactions), unlike substoichiometric TiN in vapor-phase reactions. ${ }^{13,14}$

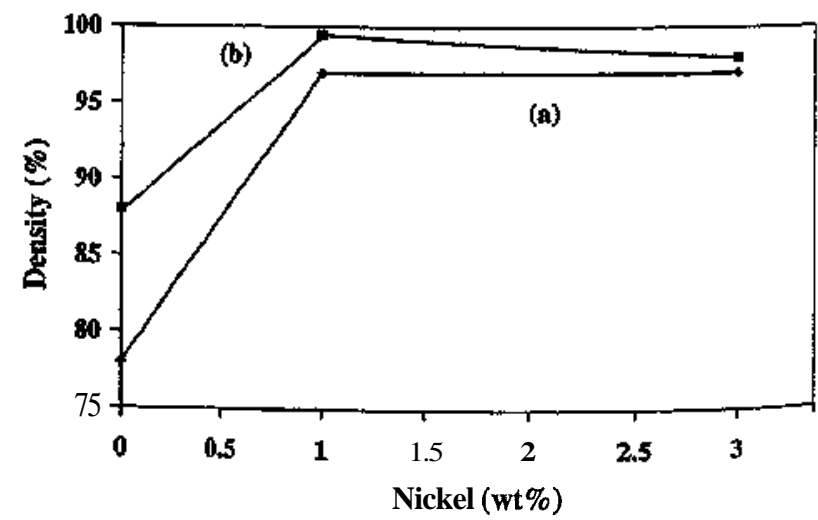

Fig. 4. Density versus nickel content plot of the composite produced at $40 \mathrm{MPa}$ for $30 \mathrm{~min}$ at (a) $1400^{\circ}$ and (b) $1600^{\circ} \mathrm{C}$. Large increase in density $(78 \%-97 \%)$ is observed at $1400^{\circ} \mathrm{C}$ with $1 \%$ nickel. Higher temperature $\left(1600^{\circ} \mathrm{C}\right)$ is required to obtain samples with $\sim 99.5 \%$ (theoretical density). 


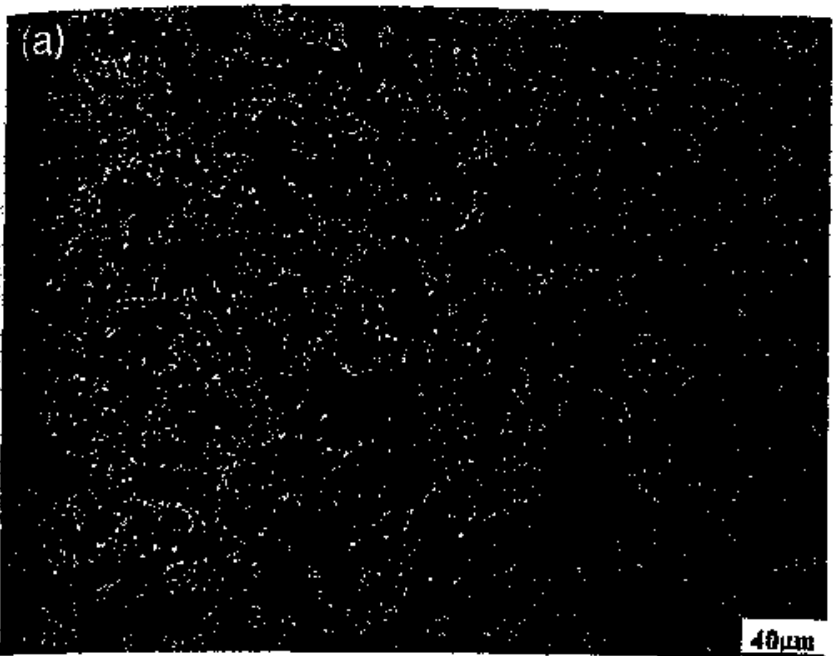

Fig. 5. Optical micrographs of the composite produced at $40 \mathrm{MPa}$ for $30 \mathrm{~min}$ at (a) $1400^{\circ}$ and (b) $1400^{\circ} \mathrm{C}$ with $1 \%$ nickel addition. Dark regions are pores; decrease in porosity is evident with addition of nickel.
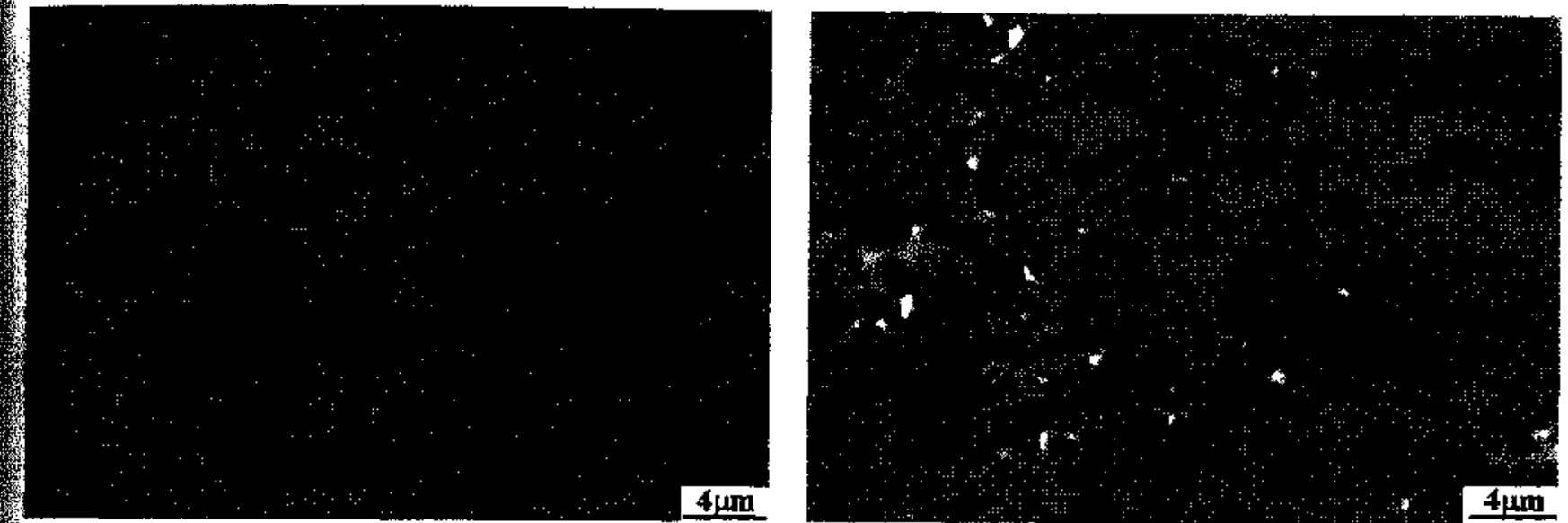

fig. 6. SEM micrographs of composite produced at $40 \mathrm{MPa}$ and $1600^{\circ} \mathrm{C}$ for $30 \mathrm{~min}$ with (a) $1 \%$ and (b) $3 \%$ nickel. Light gray, dark gray, and bright particles are $\mathrm{TiN}, \mathrm{TiB}_{2}$, and nickel phases, respectively. $\mathrm{TiB}_{2}$ phase is surrounded by $\mathrm{TiN}$ phase.

\section{2) Low-Temperature Densification $\left(1100^{\circ}-1475^{\circ} \mathrm{C}\right)$}

The results of reactive hot-pressing experiments at lower temperatures are now presented to understand the reaction kinetics and densification mechanisms involved. The role of nickel is not confined to aiding densification (Table II), but also in promoting the reaction between titanium and $\mathrm{BN}$. The reaction is completed at $1200^{\circ} \mathrm{C}$ with $1 \%$ nickel and at $1100^{\circ} \mathrm{C}$ with $3 \%$ nickel (XRD patterns in Fig. 7). The presence of $1 \%$ nickel brings about a change in composite density from $86 \%$ to $97 \%$ when produced at $1200^{\circ}-1475^{\circ} \mathrm{C}$ after $1 \mathrm{~min}$ and is higher than $78 \%$ density achieved at $1400^{\circ} \mathrm{C}$ after $30 \mathrm{~min}$ without nickel. Typical optical microstructural observations in samples containing $1 \%$ nickel

Table II. Properties of Composites with Nickel Addition ${ }^{\dagger}$

\begin{tabular}{|c|c|c|c|c|}
\hline $\begin{array}{l}\text { Sample } \\
\text { No. }\end{array}$ & $\begin{array}{l}\text { Experimental conditions }\left(\mathrm{MPa} /{ }^{\circ} \mathrm{C} / \mathrm{min} \text { ) }\right. \\
\text { (with } \mathrm{Ni} \text { addition) }\end{array}$ & $\begin{array}{l}\text { Density }\left(\mathrm{g} / \mathrm{cm}^{3}\right) \\
(\% \mathrm{RD})\end{array}$ & Porosity (\%) & Hardness (GPa) \\
\hline 15 & $\begin{array}{l}40 / 1100 / 1 \\
(1 \%)\end{array}$ & $\begin{array}{l}3.5593 \pm 0.03 \\
(70)\end{array}$ & 6.2 & \\
\hline 16 & $\begin{array}{c}40 / 1200 / 1 \\
(1 \%)\end{array}$ & $\begin{array}{c}4.3729 \pm 0.0009 \\
(86)\end{array}$ & 2.06 & $12.21 \pm 0.74$ \\
\hline $17^{\circ}$ & $\begin{array}{c}40 / 1300 / 1 \\
(1 \%)\end{array}$ & $\begin{array}{c}4.7288 \pm 0.0029 \\
(93)\end{array}$ & 0.12 & $21.48 \pm 1.53$ \\
\hline 18 & $\begin{array}{c}40 / 1475 / 1 \\
(1 \%)\end{array}$ & $\begin{array}{c}4.9627 \pm 0.0017 \\
(97)\end{array}$ & 0.02 & $21.59 \pm 0.37$ \\
\hline 19 & $\begin{array}{c}40 / 1475 / 30 \\
(1 \%)\end{array}$ & $\begin{array}{c}4.9475 \pm 0.0006 \\
(97.3)\end{array}$ & 0.01 & $22.18 \pm 1.20$ \\
\hline 20 & $\begin{array}{c}40 / 1100 / 1 \\
(3 \%)\end{array}$ & $\begin{array}{c}4.2059 \pm 0.0184 \\
(82)\end{array}$ & 6.75 & \\
\hline 21 & $\begin{array}{c}40 / 1475 / 30 \\
(3 \%)\end{array}$ & $\begin{array}{c}4.9703 \pm 0.0016 \\
(97.5 \%)\end{array}$ & & \\
\hline
\end{tabular}




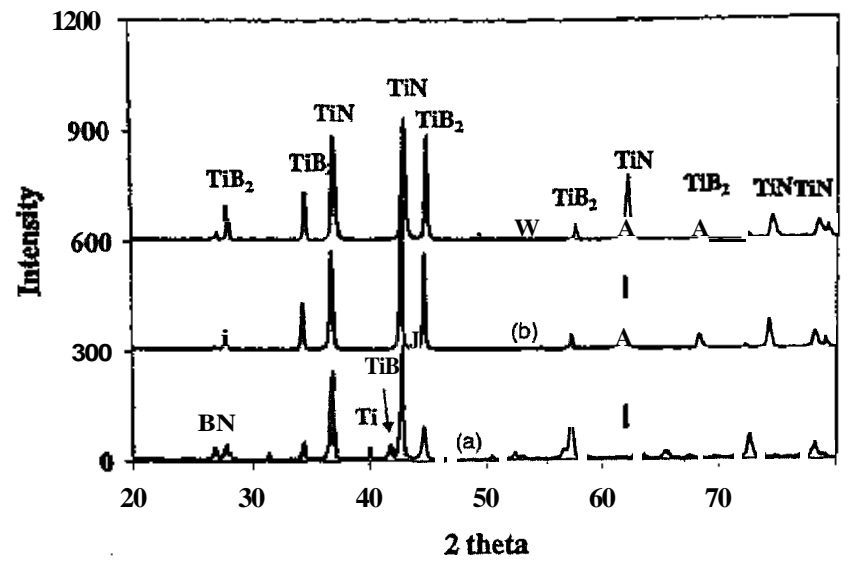

Fig. 7. XRD patterns of the composite produced at $40 \mathrm{MPa}$ for $1 \mathrm{~min}$ with $1 \%$ nickel at (a) $1100^{\circ}$ and (b) $1200^{\circ} \mathrm{C}$ and (c) $3 \%$ nickel at $1100^{\circ} \mathrm{C}$ Load application was initiated at $950^{\circ} \mathrm{C}$. Reaction is completed at $\sim 1200^{\circ} \mathrm{C}$ with $1 \%$ nickel and at $\sim 1100^{\circ} \mathrm{C}$ with $3 \%$ nickel

reveal unreacted metallic phase at $1100^{\circ} \mathrm{C}$ for 1 min (Fig. 8(a)), whereas XRD observations indicate the presence of titanium. EDAX analyses in the SEM (Fig. 9) of regions optically identified as metallic in nature in the composite with $3 \%$ nickel $\left(1100^{\circ} \mathrm{C}\right.$ for $1 \mathrm{~min}$ ) indicate the presence of intermetallic phases with compositions ranging from 27 to 88 at.\% nickel.

A clear beneficial effect of the application of pressure at low temperature is shown by the final density (Table III). Increasing the amount of nickel from $1 \%$ to $3 \%$ results in acceleration of the reaction and of densification up to $1400^{\circ} \mathrm{C}$ but leads to a marginally lower density at $1600^{\circ} \mathrm{C}$; i.e., the maximum density achievable seems to decrease even though it increases during the earlier stages.

\section{Discussion}

The role of nickel addition on reaction kinetics and densification of the composites have been presented. We now examine the above results in relation to the phase diagram of $\mathrm{Ti}-\mathrm{Ni}$ and earlier reports on liquid-phase-assisted reactive hot pressing. The following trends are clear:

(1) Up to and below $1600^{\circ} \mathrm{C}$, nickel is beneficial in densification.

(2) The maximum density achieved below $1500^{\circ}-1600^{\circ} \mathrm{C}$ does not reach theoretical density but falls short by $\sim 3 \%$, irrespective of the heating schedule used.

(3) Above $1600^{\circ} \mathrm{C}$, the role of nickel is less significant.

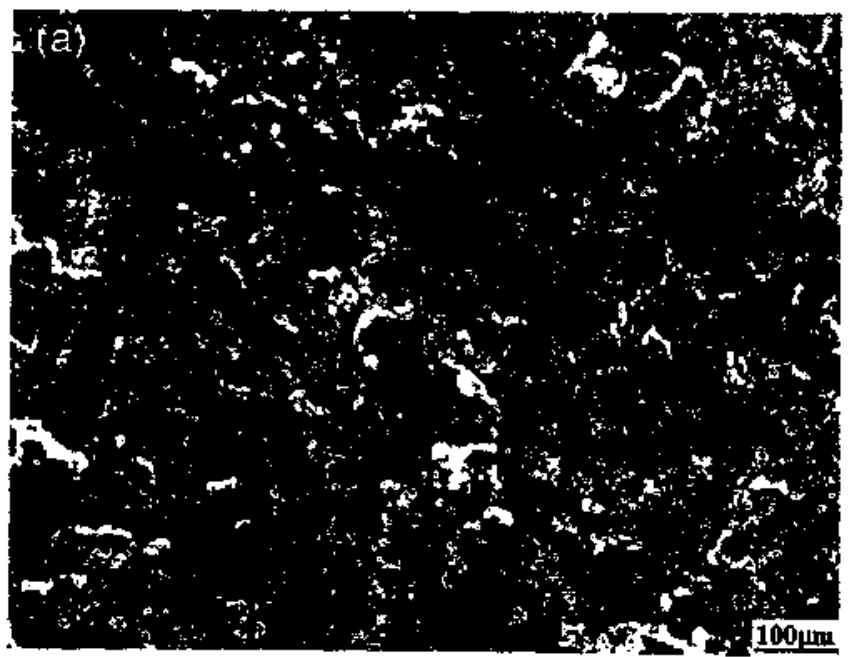

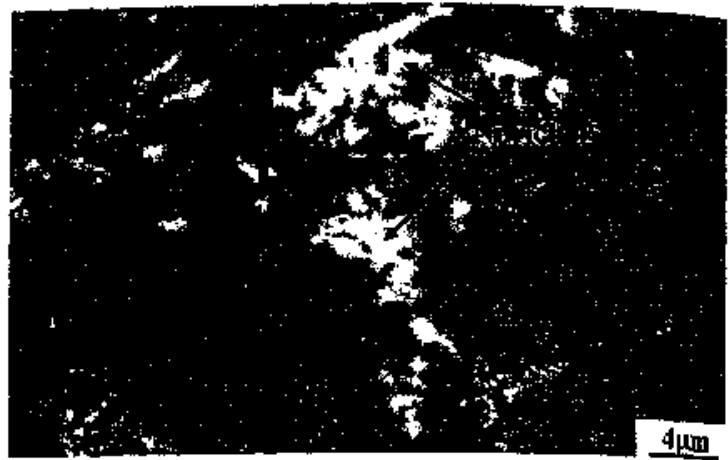

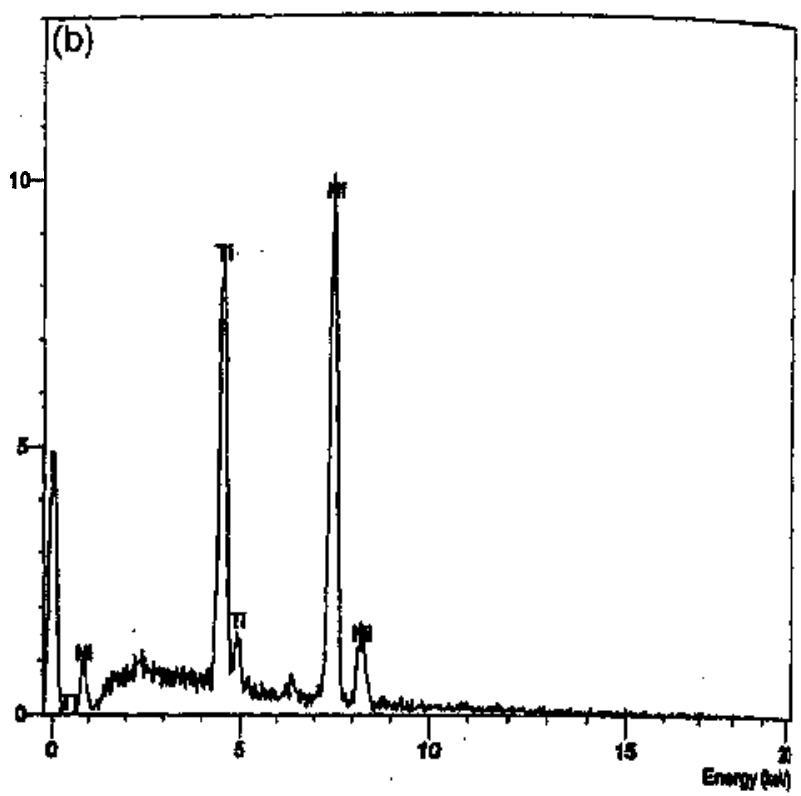

Fig. 9. (a) SEM micrograph and (b) EDAX analysis of the composite with $3 \%$ nickel produced at $40 \mathrm{MPa}$ and $1100^{\circ} \mathrm{C}$ for $1 \mathrm{~min}$ (load application was initiated at $950^{\circ} \mathrm{C}$ ). Nickel-rich phase is evident.

\section{(1) Effect of Nickel Addition on Reaction Kinetics and} Densification

The Ni-Ti phase diagram ${ }^{15}$ (Fig. 10) shows that, to obtain liquid phases in the powder mixture under equilibrium conditions. the metal content should be $12 \%$ (nickel) at $942^{\circ} \mathrm{C}$. This value

Fig. 8. Optical micr composite producd at $40 \quad \mathrm{MPa}$ and $1100^{\circ} \mathrm{C}_{\text {for }} \quad 1$ min with (a) $1 \%$ and (b) $3 \%$ nickel addition (load application was initiated at $950^{\circ} \mathrm{C}$. Bright fegions in (a) a atererunreacted titanium particles.

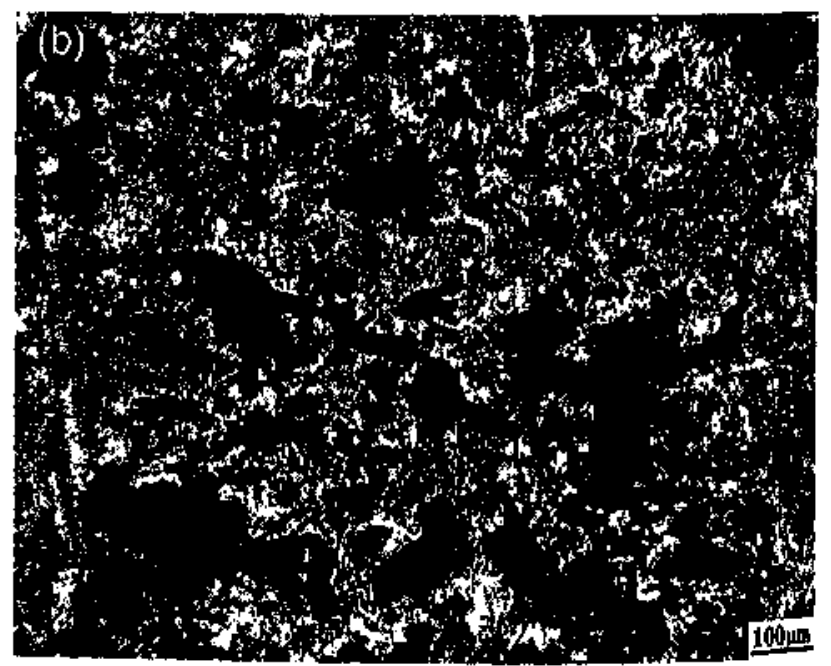


Table III. Densities of Composites Produced with Nickel Addition at Various Temperatures ${ }^{\dagger}$

\begin{tabular}{cccc}
\hline & & \multicolumn{2}{c}{ Density of the composites (\%) } \\
\cline { 3 - 4 } $\begin{array}{c}\text { Amount of nickel } \\
(\mathrm{wt} \%)\end{array}$ & $\begin{array}{c}\text { Temperature } \\
\left({ }^{\circ} \mathrm{C}\right)\end{array}$ & $\begin{array}{c}\text { Pressure application } \\
\text { started at } 950^{\circ} \mathrm{C}\end{array}$ & $\begin{array}{c}\text { Pressure application } \\
\text { started at } 1200^{\circ} \mathrm{C}\end{array}$ \\
\hline 1 & 1100 & 70 & \\
3 & 1100 & 82 & \\
1 & 1200 & 86 & 92.7 \\
1 & 1300 & 93 & 96.4 \\
1 & 1400 & & 95.5 \\
3 & 1400 & 97 & 96.5 \\
1 & 1475 & & 99.5 \\
1 & 1550 & 97.3 & \\
1 & 1600 & 97.5 & \\
3 & $1475^{*}$ & & \\
1 & $1475^{*}$ & & \\
\hline
\end{tabular}

${ }^{\ddagger} \mathrm{At} 40 \mathrm{MPa}$ for $1 \mathrm{~min}$. ${ }^{\ddagger}$ For $30 \mathrm{~min}$.

decreases to $\sim 9 \%$ at $1200^{\circ} \mathrm{C}$, but, in the present case, the amount of nickel is $1 \mathrm{wt} \%$ for the total mixture and $1.33 \mathrm{wt} \%$ with respect to titanium. Thus, for the formation of liquid under equilibrium conditions between the eutectic temperature and $1200^{\circ} \mathrm{C}$, more than $\sim 90 \%$ of the titanium should have first reacted with $\mathrm{BN}$ in the solid state. Such a scenario is unlikely, given the dominant role of nickel in promoting further reaction as well as densification. Thus, it is concluded that the onset of the reaction $\left(3 \mathrm{Ti}+2 \mathrm{BN} \rightarrow 2 \mathrm{TiN}+\mathrm{TiB}_{2}\right)$ beyond $942^{\circ} \mathrm{C}$ leads to a local decrease of the Ti:Ni ratio in the vicinity of nickel particles, thereby leading to the formation of a low-temperature liquid. Such a liquid may then promote the dissolution of $\mathrm{BN}$ at a rate that is faster than that at which titanium from the solid particles diffuses into the liquid. Only then can the alloy composition be maintained sufficiently nickel-rich to remain partially molten and to continue its role in aiding sintering. Direct evidence for this lack of equilibrium has been presented in the simultaneous presence of solid phases with compositions that lie at opposite ends of the phase diagram (Fig. 10). Such a liquid phase is transient and metastable and is in striking contrast with earlier reports $^{9-11}$ of liquid-phase-assisted processing in which substantial amounts of nickel have been added (>25\%). Addition of $3 \%$ nickel increases the volume of liquid and the rates of both processes that are driven by dissolution (reaction and densification), as is experimentally observed (Fig. 7 and Tables II and III).

\section{(2) Effect of Early Application of Pressure on Reaction Kinetics and Densification}

The beneficial role of early application of pressure also can be understood by the increase in coverage of the liquid as it is squeezed into the interparticulate porosity. The inability to obtain full density below $1500^{\circ} \mathrm{C}$ is striking and suggests that, as the reaction proceeds, once the metallic composition approaches the liquidus composition on the nickel-rich end of the phase diagram, the volume fraction of liquid is insufficient to complete densification, and solid-state transport becomes essential; i.e., higher temperatures are needed, typically $1550^{\circ}-1600^{\circ} \mathrm{C}$. This slowing in densification beyond $97 \%$ also is witnessed with $1 \%$ and $3 \%$ nickel at $1475^{\circ} \mathrm{C}$ (Table III) and in the case where pressure is applied at a lower temperature; i.e., the measures that have been introduced to increase densification in the earlier stages fail below $1475^{\circ} \mathrm{C}$, as expected, if the absence of sufficient volume fraction of liquid were the principal cause. A possible additional contributing factor is that molten nickel might not wet $\mathrm{TiB}_{2}$ and $\mathrm{TiN}$ in the absence of titanium. Both these situations might be remedied by adding a small excess of titanium above the amount required for stoichiometric conversion of the $\mathrm{BN}$ to the ceramic products,

Microstructural observations and chemical analysis using SEM indicate that, as the reaction progresses, the nickel content of the metallic phase increases locally to form a nonequilibrium liquid phase that promotes further reaction and densification at temperatures as low as $1400^{\circ} \mathrm{C}$ (Fig. 8). Thus, the sequence of events is envisaged to be as follows:

(1) The addition of a small quantity of nickel is able to form a low-temperature liquid with the neighboring titanium. This liquid phase squeezes between the particles and enhances reaction and densification by providing a high-diffusivity path, thus enabling the completion of the reaction at $\sim 1200^{\circ} \mathrm{C}$.

(2) An early application of pressure, i.e., at low temperatures $\left(950^{\circ} \mathrm{C}\right)$ during heating, promotes a uniform distribution of liquid and the formation of interparticulate contacts, thereby promoting reaction and densification.

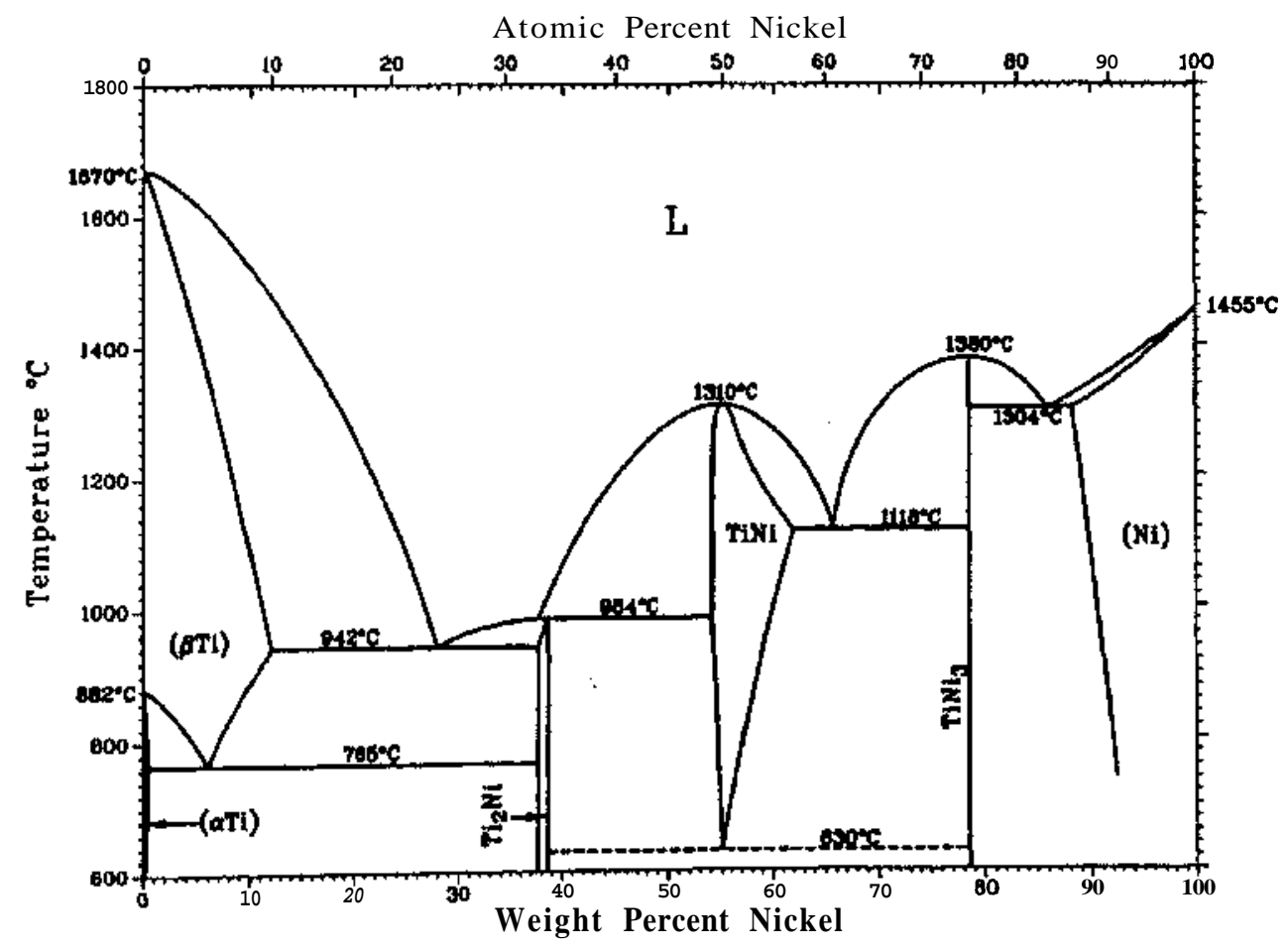

Fig. 10. Ni-Ti phase diagram. ${ }^{15}$ 
Table IV. Comparison of Results of $\mathrm{TiN}^{-\mathrm{TiB}_{2}}$ Composites Produced Eartier ${ }^{\dagger}$ and Present Study

\begin{tabular}{|c|c|c|c|c|}
\hline Material & $\begin{array}{c}\text { Conditions } \\
\left(\mathrm{MPa} /{ }^{\circ} \mathrm{C} / \mathrm{min}\right)\end{array}$ & $\begin{array}{l}\text { Density } \\
(\% R D)\end{array}$ & $\underset{(\mathrm{GPa})}{\text { Hardness }}$ & $\begin{array}{l}\text { Fracture toughness } \\
\left(\mathrm{MPam}^{6 / 2}\right)\end{array}$ \\
\hline $\begin{array}{l}\text { TiN-TiB, }(20-80 \mathrm{wt} \%)^{1} \\
\text { TiN-30 wt } \% \mathrm{TiB}_{2}^{2} \\
\mathrm{TiN}+20 \mathrm{wt} \% \mathrm{Ti}_{2} \\
\mathrm{TiN}+20 \mathrm{wt} \% \mathrm{TiB}_{2}+1.5 \mathrm{wt} \% \mathrm{Ni}^{4} \\
\mathrm{TiH}{ }_{2}-\mathrm{BN}\left(0-5 \mathrm{wt}^{4} \mathrm{Ni}\right)^{6} \\
\mathrm{Ti}-\mathrm{BN}-1.5 \mathrm{Ni}^{9-11}\end{array}$ & $\begin{array}{c}20 / 1800 / 30 \\
-11700-2000 / 90 \\
30 / 1700-1850 / 30 \\
30 / 1700-1850 / 30 \\
30 / 1850 / 30(\mathrm{RHP}) \\
\sim 150-250 / 1100-1200 / 2-20 \mathrm{~h} \text { (RHP) }\end{array}$ & $\begin{array}{l}99 \\
98 \\
98.2 \\
97.2 \\
98-99.9 \\
\sim 92-99\end{array}$ & $\begin{array}{l}18 \\
21 \\
13.7 \\
13.3 \\
20.5 \\
15-18\end{array}$ & $\begin{array}{l}3 \\
4 \\
3.8 \\
4.1 \\
6.2 \pm 0.21 \\
6.4-7.8\end{array}$ \\
\hline $\begin{array}{l}\mathrm{Ti}+\mathrm{BN} \\
\mathrm{Ti}+\mathrm{BN}(1 \mathrm{wt} \% \mathrm{Ni}) \\
\mathrm{Ti}+\mathrm{BN}(1 \mathrm{wt} \% \mathrm{Ni})\end{array}$ & $\begin{array}{l}\text { Present study } \\
40 / 1850 / 30 \\
40 / 1600 / 30 \\
40 / 1475 / 30\end{array}$ & $\begin{array}{l}98.2 \\
99.5 \\
97.3\end{array}$ & $\begin{array}{l}24.5 \pm 0.72 \\
24.5 \pm 0.97 \\
22.18 \pm 1.2 \\
\end{array}$ & $\begin{array}{l}6.03 \pm 0.4 \\
6.53 \pm 0.4\end{array}$ \\
\hline
\end{tabular}

"Literature data.

(3) Even though the reaction is completed at lower temperature and substantial densification $(-97 \%)$ is achieved at $1475^{\circ} \mathrm{C}$, the final elimination of porosity requires higher temperatures $\left(\sim 1550^{\circ} \mathrm{C}\right)$ because of the gradual disappearance of the liquid and the need for solid-state diffusion within $\mathrm{TiN}$ and $\mathrm{TiB}_{2}$.

The hardness achieved can be classified in two regions. The maximum density $(99.5 \%)$ and hardness ( $24 \mathrm{GPa})$ achieved at $1600^{\circ} \mathrm{C}$ with $1 \%$ nickel addition are similar to that fabricated at $1850^{\circ} \mathrm{C}$ without nickel addition. Significantly high hardness $(\sim 22$ $\mathrm{GPa}$ ) has been achieved at $1400^{\circ} \mathrm{C}$. Fracture toughness seems to be relatively insensitive to processing conditions once the relative density exceeds $\sim 95 \%$.

\section{(3) Comparison with Earlier Work}

Results of earlier work (literature) and present work are listed in Table IV. The temperature required for densification is high h $^{1-4}$ when pure $\mathrm{TiN}$ and $\mathrm{TiB}_{2}$ are used. Although the composites produced with larger amounts of nickel (23-25 at.\%) and higher pressure during processing $(\sim 150 \mathrm{MPa})$ result in $\sim 92 \%-99 \%$ density, the times required are longer $(\sim 2-20 \mathrm{~h})$, and their hardness is significantly lower $(14-18 \mathrm{GPa}) .^{9-11}$ The densities of the composites in the present work are similar to those obtained by Zhang et al. ${ }^{6}$ when the hot-pressing temperature is $1850^{\circ} \mathrm{C}$. Thus, the present study leads to the conclusion that the addition of a small amount nickel $(\sim 1 \mathrm{wt} \%)$ can help decrease the densification temperature to as low as $1600^{\circ} \mathrm{C}$ with a hardness of $\sim 24.5 \mathrm{GPa}$ and fracture toughness of $\sim 6.5 \mathrm{MPa} \cdot \mathrm{m}^{1 / 2}$.

\section{Conclusions}

The present detailed investigations on the reactive hot pressing of titanium and $\mathrm{BN}$ powder mixtures have led to the following conclusions.

(1) The reactive hot pressing of $\mathrm{TiN}-\mathrm{TiB}_{2}$ without nickel addition is successfully completed by reacting titanium and $\mathrm{BN}$ powder mixtures at $40 \mathrm{MPa}$ in the temperature range $1400^{\circ}-$ $1850^{\circ} \mathrm{C}$ for $30 \mathrm{~min}$.

(2) The reaction is complete without nickel at a temperature of $\geq 1600^{\circ} \mathrm{C}$, but the density achieved is only $88.8 \%$.

(3) The addition of 1 wt\% nickel produces $99.5 \%$ dense composites at temperatures as low as $1600^{\circ} \mathrm{C}$ after $30 \mathrm{~min}$. The hardness and fracture toughness of the composites are $\sim 24 \mathrm{GPa}$ and $\sim 6.5 \mathrm{MPa} \cdot \mathrm{m}^{1 / 2}$, respectively.

(4) The role of nickel appears to be the formation of a low-temperature liquid as the neighboring titanium reacts with BN. This liquid phase provides a high diffusivity path, which enables the completion of the reaction at a temperature as low as $-1200^{\circ} \mathrm{C}$.
(5) An early application of pressure during heating can bring about densities as high as $97 \%$ at a temperature as low as $1475^{\circ} \mathrm{C}$. Even though the reaction is completed at a lower temperature and substantial densification is achieved at $1475^{\circ} \mathrm{C}$, the final elimination of porosity requires higher temperature because of the gradual disappearance of the liquid and the need for solid-state diffusion within $\mathrm{TiN}$ and $\mathrm{TiB}_{2}$.

\section{Acknowledgment}

The work that has been reported is a result of support from the Director of NAL, Head of Materials Science Division, and many colleagues in the Materials Science Division of NAL. The authors are indebted to P. M. Jaman and V. Babu for the assistance in hot-pressing experiments, S. Usha Devi for XRD measurements, M. A, Venkataswamy and Kalavati for SEM work, and K. V. Ramaiah for optical microscopy.

\section{References}

${ }^{1} \mathrm{~K}$. Shobu and T. Watanabe, "Hot Pressing of TiN-TiB 2 System," J. Powder Metall. Soc. Jpn., 32 [6] 215-18 (1995).

T. Watanabe, H. Yamamoto, K. Shobu, and T. Sakamoto, "Factors Affecting the Porosity and Bending Strength of Ti(CN)-TiB 2 Materials," J. Am. Ceran. Soc, 71 [4] C-202-C-204 (1987)

${ }^{3} \mathrm{~K}$. Shobu, T. Watanabe, Y. Enomoto, K. Umeda, and Y. Tsuya, "Frictional Properties of Sintered $\mathrm{TiN}_{-} \mathrm{TiB}_{2}$ and $\mathrm{Ti}(\mathrm{CN})-\mathrm{TiB}$, Ceramics at High Temperature." J. Am. Ceram. Soc., 70 [5] C-103-C-104 (1987)."

${ }^{4}$ T. Graziani, C. Melandri, and A. Bellosi, "Fabrication of Monolithic TiN and TiN-20-vol\%-TiB 2 Composites," J. Hard Mater, 4, 29-36 (1993).

${ }^{5} \mathrm{G}$. J. Zhang, "Preparation of $\mathrm{TiB}_{2}-\mathrm{TiC}_{0.5} \mathrm{~N}_{0.5}$ Ceramic Composite by Reactive Hot Pressing and Its Microstructure," Ceram. Int., 21 [1] 29-31(1995).

${ }^{6} \mathrm{G}$. J. Zhang, Z. Z. Jin, and X. Yue, "TiN-TiB 2 Composites Prepared by Reactive Hot Pressing and Effects of Ni Addition," J. Am. Ceram. Soc., 78 [10] 2831-33 (1995).

${ }^{7} \mathrm{R}$. Tomoshige, A. Murayama, and T. Matsushita, "Production of TiB,-TiN Composites by Combustion Synthesis and Their Properties," ,. Am. Ceram. Soc., 80 [3] 761-64 (1997).

${ }^{8}$ J. W. Lee, Z. A. Munir, M. Shibuya, and M. Ohyanagi, "Synthesis of Dense $\mathrm{TiB}_{2}$-TiN Nanocrystalline Composites through Mechanical and Filed Activation," J. Am. Ceram. Soc., 84 [6] 1209-16 (2001).

${ }^{9}$ F. Olevsky, P. Mogilevsky, E. Y. Gulmanas, and I. Gotman, "Synthesis of in Situ $\mathrm{TiB}_{2} / \mathrm{TiN}$ Ceramic Matrix Composites from Dense BN-Ti and BN-Ti-Ni Powder Blends," Metall Mater. Trans., 27A, 2071-79 (1996).

${ }^{10}$ I. Gotman, N. A. Travitzky, and E. Y. Gutmanas, "Dense in Situ TiB 2 TiN and $\mathrm{TiB}_{2} / \mathrm{TiC}$ Ceramic Matrix Composites: Reactive Synthesis and Properties," Mater. Sci. Eng., A244, 127-37 (1998).

${ }^{11}$ E. Y. Gutmanas and I. Gotman, "Reactive Synthesis of Ceramic-Matrix Composites Under Pressure," Ceram. Int., 26, 699-707 (2000).

${ }^{12}$ K. Nithara, R. Morena, and D. P. H. Hasselman, "Evaluation of $K_{\text {IC }}$ of Brittle Solids by the Indentation Method with Low Crack to Indent Ratios," J. Mater. Sci. Lett., 1, 13-16 (1982).

${ }^{13}$ L. E. Toth, Transition-Metal Carbides and Nitrides, Vol. 7; p. 87. Academic Press, New York, 1971.

${ }^{14}$ S. Nagakura, T. Kusunoki, F. Kakimoto, and Y. Hirotsu, "Lattice Parameter of the Non-Stoichiometric Compound TiN ${ }_{x}$, J. Appl. Crystallogr., 8, $65-66$ (1975).

${ }^{15}$ Alloy Phase Diagrams, ASM Handbook, Vol. 3; "p, 2.319. ASM International Materials Park, OH, 1992. 